\title{
Progress in climate change adaptation and mitigation actions in sub-Saharan Africa farming systems
}

\author{
Pamela M.K. Afokpe ${ }^{1}$, Austin T. Phiri ${ }^{2,}{ }^{*}$, Alemayehu Abebe Lamore ${ }^{3}$, Howele M.A.C. Toure ${ }^{4}$, \\ Rokiatou Traore ${ }^{5}$ and Oliver Kipkogei ${ }^{6}$ \\ ${ }^{1}$ Laboratory of Genetics, Horticulture and Seed Sciences, University of Abomey-Calavi, Faculty of Agronomy, Abomey-Calavi, Benin \\ 2 Department of Agricultural Research Services, Ministry of Agriculture, Lilongwe, Malawi \\ ${ }^{3}$ Ethiopian Institute of Agricultural Research, Livestock Research Process, Addis Ababa, Ethiopia \\ ${ }^{4}$ Centre d'Excellence Africain sur le Changement Climatique, la Biodiversité et l'Agriculture Durable, Ex-ESIE, Bingerville, Pôle \\ Scientifique Université Felix Houphouët-Boigny (UFHB), Abidjan, Côte d'Ivoire \\ ${ }^{5}$ Herou Alliance, Promotion and Commercialization of Moringa for Climate Change Adaptation, Economic and Social Inclusion, \\ Bamako, Mali \\ ${ }^{6}$ Intergovernmental Authority on Development (IGAD) Climate Prediction and Application Centre (ICPAC), Nairobi, Kenya
}

\begin{abstract}
This paper reviews the progress in climate change adaptation and mitigation actions in subSaharan Africa farming systems. Farmers, organizations and Governments in the region have developed policies and innovations to adapt to and mitigate the impacts of climate change. It appears that the developed and implemented innovative adaptive farming systems and technologies have culminated into resultant overall productivity improvement in farming systems, necessitating scaling up in order to widely strengthen the resilience and adaptive capacity of vulnerable communities to the impacts of climate change. Additionally, climate governance instruments that are aligned to the ratified international treaties have been developed and related programs have been rolled out in different countries. This offers hope for wellcoordinated efforts and interventions for the mitigation and adaptation to the adverse impacts of climate change on the environment and livelihoods. Observably, there is a pressing need to scale up climate smart innovations sustainably through creation of an enabling policy environment, capacity building, and conducting climate change related research and outreach, and effective dissemination of climate technologies and information, especially in remote areas in the region. Since climate change is a global issue, local initiatives and actions for mitigating and adapting to the adverse impacts ought to be well integrated into the broader international context.
\end{abstract}

Keywords: farming system / innovations / policy / climate / agriculture / sub-Saharan Africa

Résumé - Progrès dans l'adaptation au changement climatique et les actions d'atténuation dans les systèmes agricoles de l'Afrique subsaharienne. Cet article passe en revue les progrès des mesures d'adaptation au changement climatique et d'atténuation de ses effets dans les systèmes agricoles d'Afrique Subsaharienne. Les producteurs, les organisations et les gouvernements de la région ont mis au point des innovations et des politiques pour s'adapter au changement climatique et atténuer ses effets. Il apparaît que les technologies et les systèmes agricoles adaptatifs innovants développés et mis en œuvre ont abouti à une amélioration de la productivité des systèmes agricoles, mais qu'ils nécessitent une généralisation afin de renforcer plus largement la résilience et la capacité d'adaptation des communautés vulnérables aux impacts du changement climatique. En outre, des instruments de gouvernance climatique cohérents avec les traités internationaux ratifiés ont été élaborés et des programmes de mise en oeuvre ont été lancés dans différents pays. Cela laisse espérer des efforts et des interventions bien coordonnés pour l'atténuation et l'adaptation aux effets néfastes du changement climatique sur l'environnement et les moyens de subsistance. Il est urgent de développer durablement les innovations climato-intelligentes en créant un environnement politique favorable, en renforçant les capacités, en menant des recherches et des activités de sensibilisation liées au changement climatique, et en diffusant efficacement les technologies et les informations climatiques, en

*Corresponding author: phiriaustin534@gmail.com 
particulier dans les zones reculées de la région. Le changement climatique étant un problème mondial, les initiatives et les actions locales d'atténuation et d'adaptation aux impacts du changement climatique doivent s'intégrer dans le contexte international.

Mots clés : système agricole / innovations / politique / climat / agriculture / Afrique subsaharienne

\section{Introduction}

Sub-Saharan Africa (SSA) is well endowed with natural resources, having abundant arable land and a vast agricultural growth potential (Shimeles et al., 2018). However, the agriculture sector is characterized by low productivity hence by food insecurity emanating from environmental challenges and other structural and institutional factors (FAO, 2016). Main causes include climate change and the lack of coping capacity, low use of appropriate agricultural inputs and soil and water management strategies and inefficient agricultural research and extension systems (FAO, 2016). The sector, dominated by smallholder agriculture, hires close to $54 \%$ in the formal work sector on the continent. Hence, the disruptive effects of the unstable climate in the agricultural sector also affect the region's economy (Shimeles et al., 2018). Climate change effects like the rise in temperature, decline in rainfall (Fig. 1), rise in sea level in coastal areas, late and intensive rains, extreme winds, drought and floods, are adversely affecting agricultural productivity and production, hence, causing decrease in incomes, low adaptive capacity among farming households, high and rising food prices, economic losses, and undermining food security (Zougmoré et al., 2016). Predictions of the beginning and the end of rainy seasons become less accurate with a tendency of delayed onset and later retreat and no harmony in rainfall patterns (Zamudio, 2016), thereby making planning of farm operations difficult. The region has diverse farming systems including wetland rice based, rain-fed farming, mixed crop-livestock and pastoral systems, irrigated farming systems, humid lowland tree crop, root and tuber crops, cereal-root crops mixed and maize mixed systems (Zougmoré et al., 2016). Meanwhile, countries in Africa and farmers have innovated adaptation and mitigation methods to cope with climate change. Some of the adaptation strategies for the improvement of crop productivity include diversification of crops and income sources, integrated soil fertility management (ISFM) and soil moisture and water conservation practices (Akinnagbe and Irohibe, 2014), while mitigation strategies like agroforestry contribute to climate change mitigation through atmospheric carbon capture (Nath et al., 2021). The paper therefore explores farming systems present in Eastern, Western and Southern Africa to illustrate the progress made in climate change adaptation and mitigation actions both at policy and farm level. Examples are drawn from Benin, Côte d'Ivoire and Mali in Western Africa, Ethiopia and Kenya in Eastern Africa and Malawi in Southern Africa.

\section{Methodology}

A systematic literature review was performed to identify, summarize and analyze the progress in climate change adaptation and mitigation actions in sub-Saharan Africa farming systems with a focus on the following countries: Benin, Côte d'Ivoire, Ethiopia, Kenya, Malawi and Mali.
These six countries, being the countries of origin of the authors of this paper, were chosen to facilitate a better review of the national climate change policies and strategies using the respective national perspectives. In addition to that, the six countries are among the most vulnerable countries to climate change effects (GoK, 2018; Goula Bi Tié et al., 2006; IIED, 2004; Simane et al., 2016; Tye and Waslander, 2021; Zamudio, 2016). The review consisted of retrieving relevant research papers from online databases such as ResearchGate, PubMed, Scopus, Google, Google Scholar, PMC free articles, Springer Link African Crop Science Journal and Wageningen Journal of Life Science based on specific keywords. The search included the following keywords: farming systems, SSA, climate change, agriculture, innovations, policies, international treaties, adaptation, mitigation and national adaptation program. The official reports and database of the Food and Agriculture Organization (FAO) database, the United Nations Framework Convention on Climate Change (UNFCCC), the Intergovernmental Panel on Climate Change (IPCC), and the International Fund for Agricultural Development (IFAD) were also reviewed including the countries fact sheets and national climate reports and databases of the selected countries.

\section{Progress in developing national policies and strategies aligned to international agricultural policy instruments on climate change adaptation/mitigation in sub-Saharan Africa}

In response to the threats of climate change, many countries in SSA have joined the international community in mainstreaming and implementing international climate policies which have shaped their national policies and strategies. In regard to the international policies, three main international treaties are implemented and ratified by countries in SSA. The ratification timeline of these international treaties by the respective countries is slightly different (Tab. 1). The treaties include the UNFCCC implemented in 1992 which represents the main international treaty in fighting climate change. A second important international treaty is the Kyoto protocol for the reduction of greenhouse gas emissions globally (GHGs) that was signed in 1997 and entered into force in 2005. In addition to the above-mentioned treaties, a third treaty is the Paris agreement adopted by UNFCCC parties in 2015 as a legal binding global agreement to fight climate change and adapt to its effects (UNFCCC, 2015). This treaty aims mainly at reinforcing the capacity of countries to combat the impacts of climate change with a specific weight put on agriculture. Generally, most of the climate change related mitigation and adaptation strategies formulated by most parties of the UNFCCC are linked to agriculture.

To facilitate the implementation of the international policies, some countries have reshaped their existing national policies and strategies, while others have developed new 


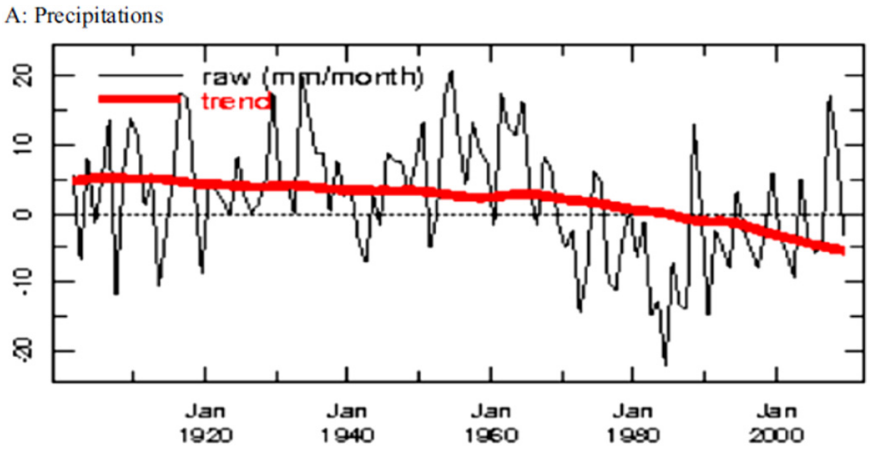

B: Temperature

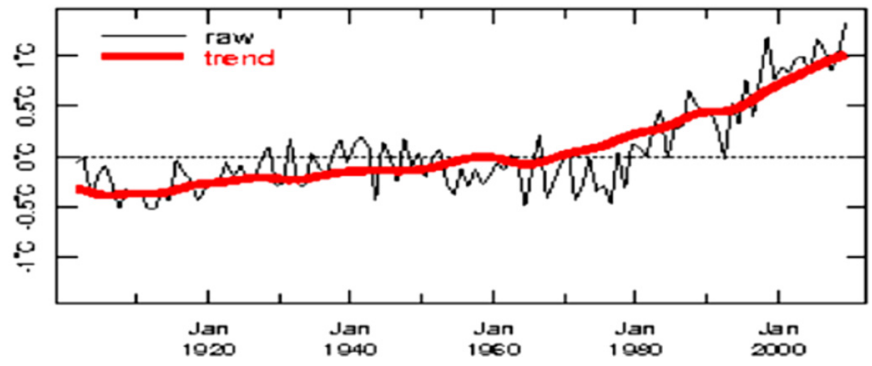

Fig. 1. Changes in precipitations (A) and temperature (B) in Africa recorded from 1920 to 2000. Source: Zougmoré et al. (2016).

Fig. 1. Modifications des précipitations et des températures en Afrique enregistrées entre 1920 et 2000. Source: Zougmoré et al. (2016).

national frameworks of action in accordance with those international agreements. In that line, Ethiopia and Malawi have derived their National Adaptation Program of Action (NAPA) from UNFCCC in 2007 (Amsalu and Gebremichael, 2010). NAPA offers a structure to direct the harmonization and execution of adaptation and mitigation strategies of the Governments in synergy with other climate change related projects and programmes (FAO, 2016). This includes the identification of a list of priority activities, the formulation of adaptation options, capacity building and awareness of the public on the urgency of climate change adaptation in line with UNFCCC standards. However, the lack of funding has hampered the implementation of NAPA in some SSA countries, particularly in Ethiopia (Nyasimi et al., 2013). In addition to NAPA, Malawi formulated a National Climate Change Management Policy (GoM, 2012b) and National Climate Change Investment Plan (NCCIP). The National Climate Change Management Policy creates an enabling policy and legal framework for a pragmatic, coordinated and harmonized approach to climate change management (GoM, 2016) while the National Climate Change Investment Plan (NCCIP) essentially provides direction on the apportioning of financial resources to critical areas in climate change adaptation and mitigation effort (GoM, 2013).

To implement the UNFCCC, Benin submitted its Intended Nationally Determined Contributions (INDC) to the Secretary of the UNFCCC in September 2015 (RoB, 2011). Besides, Benin signed the United Nations Convention to Combat Desertification (UNCCD), the United Nations Convention on Biological Diversity (CBD) and the Convention on
International Trade in Endangered Species of Wild Fauna and Flora (CITES) (RoB, 2011). These treaties successfully enforce the global climate change adaptation and mitigation strategies in the country such as the effective implementation of the Nationally Determined Contribution (NDC), the National Adaptation Program of Action (NAPA) and the National Communications with regard to climate change.

Referring to actions in Côte d'Ivoire, the Government signed the African Convention on the Conservation of Nature and Natural Resources and the Rio Convention on Biological Diversity (Dje, 2014). In 2012, it also consented to the Global Institute for Green Growth to facilitate the country's access to the knowhow in contending with the negative impacts of climate change (Magoum, 2020). In Kenya, actions went towards the establishment of the National Climate Change Response Strategy (2010), the first National Climate Change Action Plan (2013-2017), the National Adaptation Plan (NAP 2015-2030), the Kenya Climate Smart Agriculture Strategy (2017-2026), the Climate Risk Management Framework (2017) and the National Climate Change Finance Policy (2018) to implement the UNFCCC (GoK, 2018).

Under the Paris agreement, Benin developed a National Action Plan (NAP 2016-2021) based on the agenda 2030 on sustainable development to address climate adaptation and mitigation. The NAP consists of developing strategies for intensive afforestation, improved forests and coastal areas management and improving the energy sector among others (DGEC, n.d). Furthermore, to align with the same agreement, Benin's National Assembly has passed a climate change legislation, making the country one of the first to adopt such legislation (IISD, 2018). It aims to combat climate change and its negative impacts and increase the resilience of communities. Going forward, the legislation is expected to be incorporated in all national and local-level development strategies to help the country prevent, protect against and manage the consequences of climate change. In the same line, Kenya made the Paris Agreement to be part of the Kenyan law in the article 2(6), 2017 of the country constitution. The law is now being operationalized domestically through rolling out at different levels a governing framework consisting of laws, policies, plans and institutions in response to climate change (GoK, 2018). Furthermore, Mali has ratified most of the international treaties like the UNFCCC in December 1994, the Kyoto Protocol in March 2002, the Doha Amendment to the Kyoto Protocol in December 2015, and the Paris Agreement in September 2016 and is also party to the Great Green Wall (USDA, 2021). Some plans under the Paris agreement for Mali involve the implementation of inclusive and green sustainable economic development that includes establishing a monitoring and evaluation system to support the implementation of the NDC and formulation of an investment plan to support the process of attaining the emission reduction objectives (USDA, 2021)

From the analysis of the translation of the various international policies and treaties into national policies in SSA countries, it was observed that most of the relevant climate change adaptation and mitigation strategies mainly have been derived from the UNFCCC and the Paris Agreement. Apparently, there were no relevant and concrete actions derived from the Kyoto Protocol in some countries in SSA. However, some actions derived from the two others 
Table 1. Ratification timeline of UNFCCC, Kyoto Protocol and Paris Agreement by six climate vulnerable SSA countries.

Tableau 1. Calendrier de ratification de la CCNUCC, du Protocole de Kyoto et de l'Accord de Paris par six pays d'Afrique subsaharienne vulnérables au climat.

\begin{tabular}{llll}
\hline Countries & UNFCCC & Kyoto protocol & Paris agreement \\
\hline Benin & Jun 1994 & Feb 2002 & Oct 2016 \\
Côte d'Ivoire & Nov 1994 & Apr 2007 & Oct 2016 \\
Ethiopia & Apr 1994 & Apr 2005 & Mar 2017 \\
Kenya & Aug 1994 & Feb 2005 & Dec 2016 \\
Malawi & Apr 1994 & Oct 2001 & Jun 2017 \\
Mali & Dec 1994 & Mar 2002 & Sep 2016 \\
\hline
\end{tabular}

Sources: https://treaties.un.org/Pages/ViewDetailsIII.aspx?src=IND\&mtdsg_no=XXVII-7\&chapter=27\&Temp=mtdsg3\&clang=_en;https:// treaties.un.org/Pages/ViewDetails.aspx?src=TREATY\&mtdsg_no=XXVII-7-d\&chapter=27\&clang=_en.

https://en.wikipedia.org/wiki/List_of_parties_to_the_Kyoto_Protocol.

treaties are in some way contributing to reducing the emissions of greenhouse gas emissions globally. For instance, the implementation of actions in accordance with the ratification of the United Nations Convention to Combat Desertification such as reforestation could lead to a significant contribution to the reduction of the emission of GHGs globally.

\section{Progress in implementing national agricultural policies and strategies on climate change adaptation/mitigation}

Implementation is "the process of putting a decision or plan into effect". In this sense, arising from some of the developed policies, strategies and plans to combat climate change and its impacts, considerable efforts in that direction at country level have been made by the Governments in SSA. Resources are being mobilized to roll out programs aimed at achieving the objectives of formulated strategies (Tab. 2). For instance, among many medium- and long-term plans and focused policies since early 2000s, Ethiopia developed and launched the "Climate Resilient Green Economy (CRGE) Strategy" in 2011, which was "the first of its kind in Africa" (Irish Aid, 2018). The CRGE emphases four pillars which encompass the espousal of agronomic and soil management practices, improved sequestration of GHGs, utilization of renewable energy, production of clean energy and deployment of suitable innovative technologies. The Ministry of Agriculture is coordinating a pilot program in 27 districts across the four principal regions called "Agriculture Sector Fast Track CRGE" (FAO, 2016). Climate change adaptation is addressed mainly under natural resource management. It involves sustainable land use management, research on new crops and farming that withstand drier conditions exacerbated by climate change, improved water harvesting, and improved weather forecasting and risk management measures aimed at coping with climate variability in the country (FAO, 2016).

In Benin, initiatives stemming from the NAPA have already yielded results such as the establishment of a technical coordination unit, the cultivation of short cycle crops that can better withstand drought, building resilience of rural communities, spreading climate information in 35 towns and institution of 60 field schools, capacity building of rural communities to minimize the risk of flooding (RoB, 2011).
Regarding the mitigation actions, Benin has no commitment to reduce emissions under the Climate Change Convention or the Kyoto Protocol. Nevertheless, the country has proposed three potential Nationally Appropriate Mitigation Actions (NAMAs), which are "the development of less pollutant transport system to reduce GHG emissions, the sustainable development and management of natural forests resources and forest planting to strengthen carbon sinks and the recovery of $\mathrm{CH}_{4}$ (methane) emitted by landfills in some local communities" (RoB, 2011). A low-carbon development strategy resilient to climate change has been drawn up and extends over the period 2016-2020 (RoB, 2011).

Likewise, the Government of Mali allocates a great importance to climate change mitigation on its agenda. An example of adaptive action in Mali is the FAO's project of strengthening Malian farmers' capacities to adapt to climate change (ZEF et al., 2017). The project has established a network of Farmer Field Schools (FFS) to train farmers about adaptation strategies and tools in the agriculture, forestry and pastoralist sectors. Additionally, the Malian Agricultural Research for Development Center and the USAID Soil Management Collaborative Research Support Program have developed the ridge tillage technique, a groundbreaking soil conservation method that involves drawing long-lasting ridges on the fields, reducing erosion and increasing rainwater infiltration (ZEF et al., 2017).

Similarly, through implementing the commitments in the Intentionally National Determined Contribution (INDC), Côte d'Ivoire aims to modernize agricultural production techniques, intensify animal, fishery and agricultural production while conserving the forest and water resources (Yapi, 2019). The Ivorian Government developed a National Greenhouse Gas Mitigation and Adaptation Program to transform the challenges of climate change into sustainable development opportunities (Dje, 2014). The National Agricultural Investment Program (PNIA) has also been developed and presents six programs for the improvement of agricultural production, sustainable management of forest and fisheries resources. Some projects, such as Agricultural Productivity Program in West Africa, Agricultural Sector Support Project, a project on the restoration of agro-pastoral dams and the management of transhumance, have been implemented (PNIA, 2017). The Government is also involved in the REDD+ mechanism to mitigate greenhouse gas emissions (PNIA, 2017). There is also 
Table 2. Examples of some strategies implemented in response to climate change in selected countries in SSA.

Tableau 2. Exemples de certaines stratégies mises en æuvre en réponse au changement climatique dans certains pays d'Afrique subsaharienne.

\begin{tabular}{|c|c|c|c|c|c|}
\hline Country & Strategy & Vision/Objective & Time span & Target & Budget \\
\hline Ethiopia & $\begin{array}{l}\text { Climate Resilient Green } \\
\text { Economy (CRGE) } \\
\text { Strategy }\end{array}$ & $\begin{array}{l}\text { Achieve middle-income } \\
\text { status by } 2025 \text { in a } \\
\text { climate-resilient green } \\
\text { economy }\end{array}$ & $2010-2025$ & Economy & US\$ 150 billion \\
\hline \multirow[t]{2}{*}{ Malawi } & $\begin{array}{l}\text { Program for Rural } \\
\text { Irrigation Development }\end{array}$ & $\begin{array}{l}\text { Reduce vulnerability to } \\
\text { food insecurity, to climate } \\
\text { change effects and to the } \\
\text { vagaries of the market }\end{array}$ & 2016-2023 & $\begin{array}{l}\text { Rural small- } \\
\text { scale } \\
\text { irrigation } \\
\text { farmers }\end{array}$ & US\$ 85 million \\
\hline & $\begin{array}{l}\text { Malawi's Strategy on } \\
\text { Climate Change Learning }\end{array}$ & $\begin{array}{l}\text { Strengthen human } \\
\text { resources and skills } \\
\text { development for the } \\
\text { advancement of green, low } \\
\text { emission and climate } \\
\text { resilient development }\end{array}$ & $2021-2030$ & $\begin{array}{l}\text { Environment } \\
\text { and Natural } \\
\text { Resources } \\
\text { Management }\end{array}$ & US\$ 9.9 million \\
\hline Kenya & $\begin{array}{l}\text { National Climate Change } \\
\text { Response Strategy and } \\
\text { National Climate Change } \\
\text { Action Plan }\end{array}$ & Adaptation and mitigation & $2010-2030$ & Multi-sector & US\$ 2.75 billion per year \\
\hline
\end{tabular}

Sources: GoM (2021); IFAD (2015); Irish Aid (2018); Magoum (2020); Nzau (2014).

a National Strategy for Disaster Risk Management on climate risks management (FAO et al., 2018). Using the national initiative for combating climate change, the country embarked on a project to integrate climate change adaptation in developmental planning (Magoum, 2020). The aim is to build adaptive communities and empower populations to improve the capability to deal with climatic threats (Magoum, 2020).

The Government of Malawi has prioritized adaptation in order to build the resilience of communities and fragile ecosystems (Kamdonyo, 2019). Key programs, projects and activities on adaptation include; "the Green Belt Initiative (GBI)", a project designed to use water from water bodies in the country to improve agricultural production, food, nutrition and income security; instituting a national climate change management structure; assisting people in rural areas increase their adaptive capacity through empowerment with methods and techniques under the Climate Adaptation for Rural Livelihoods and Agriculture (CARLA) initiative; creating a repository of current and intended climate change-related activities; promoting soil and water management in MiddleShire under the "Sustainable Land Management program" (GoM, 2012a); and enhancing smallholder farmers' resilience to climate change through promotion of irrigation farming under the Program for Rural Irrigation Development (PRIDE) (IFAD, 2015).
Additionally, the Government of Kenya has developed policies to combat the effects of climate change and to promote adaptation strategies through timely and efficient dispatch of climate information to farmers and ensure best agricultural practices in the country through knowledge sharing, extension services, and financial support to vulnerable farmers across the country (Hesse and Pattison 2013).

\section{Innovations developed for climate change adaptation and mitigation in sub-Saharan Africa farming systems}

In response to the changing conditions, there have been efforts toward developing innovations that can support the region in dealing with climate change, both by farmers and organizations. Several organizations have been involved in the development and implementation of innovations in the following categories: water management, information initiatives, organization initiatives, soil and crop management and diversification.

Some of the developed water management innovations include: large scale irrigation schemes and farmer led microirrigation technologies like the use of bucket kits, sprinklers, tube emitters, shifting drip irrigation, etc. for optimizing 
irrigated agriculture by smallholder farmers in wetlands, along perennial rivers and streams (Fan et al., 2018); and construction of dykes to divert water into rivers in flood prone areas (GoM, 2012c). Information initiatives include for example programs developed to pass climate information to farmers through mobile phones and computers owned by either farmers or extension officers (Krell et al., 2020). Organizational initiatives include approaches such as Green Innovation centers (GICs) that aim to promote agricultural innovation, improve food and nutrition security and build sustainable value chains in the agri-food sector. GICs focuses on rice, potatoes, vegetables and fruit value chains (ZEF et al., 2017).

Soil and crop management innovations include programs like the West Africa Agricultural Productivity Program (WAAPP) and ICRISAT-HOPE project for the Sahel that have contributed to the introduction of new, early maturing, more resilient crop varieties to maintain a steady production level during rainy seasons and ensure their availability during shortage times (ZEF et al., 2017). Additionally, as an adaptation practice, some farmers plant millet and sorghum in one field and decide according to the rainfall pattern which crop to eliminate. This practice is known as "sequential adjustments" to changing weather conditions (Jansen and Vellema, 2011). Some maize farmers are adjusting the sowing time and using improved crop varieties (Soglo and Nonvide, 2019).

On diversification innovations, farmers have adopted "Mixed agro-pastoralism" practices and engaged in fishing and hunting when possible (Crane et al., 2011). Drought tolerant crops, crop associations or mixed cropping, cereal-legume intercropping, agroforestry and conservation agriculture are also used by farmers in their cropping systems to mitigate the risks of low yields (Yegbemey et al., 2017). There is also the promotion of vitamin A rich and drought tolerant orange fleshed sweet potato among smallholder farmers (GoM, 2012c). Furthermore, in the vegetable sector, multifunctional cropping systems are also recommended as adaptation strategies. This includes the integration of crop and soil management and bio-control-based integrated pest management to attenuate abiotic and biotic stresses. Also, the multiple cropping of different vegetable species and varieties in intercropping, mixed cropping to grow nutrient-rich vegetable crops, reduce the incidence of diseases and pests, increase nutrient and water use efficiency, productivity and yields. These interventions may enhance production of vegetables thereby contributing to improved household nutrition. Additionally, multiple cropping systems with diverse vegetable types generally aim to enhance dietary diversity (Rajendran et al., 2017), while scaling up agroforestry technologies like fertilizer and fruit trees to improve soil fertility, sequester carbon and improve food, incomes and nutrition security; the development of fish ponds for water harvesting and integrated fish farming and forest co-management and apiculture are also being supported (GoM, 2012c).

\section{Impacts and scaling of innovations for enhancing climate change adaptation and mitigation in sub-Saharan Africa farming systems}

Positive impacts of climate innovations have been reported in SSA under various initiatives. Among the listed impacting innovations are: agricultural diversification, enhanced natural resource management, soil and crop management, climate information initiatives and water management. Examples of agricultural diversification include the livestock pass-on program, use of improved and stable seed varieties with success stories registered in Mali. For instance, under the FAO project in that country, yield of sorghum has improved with 21 and up to $97 \%$ through use by farmers of hybrid seed (FAO, 2018). The project has helped 41000 smallholder farmers to improve the climate change resilience (FAO, 2018). Furthermore, in Malawi, natural resources management has been enhanced through capacity building in natural resources management committees leading to better management of forest resources and the subsequent thriving forested areas due to the reduction of the felling of trees (GoM, 2012c). In terms of soil and crop management, initiatives have led to improved crop productivity, for instance, the ICRISAT-HOPE project for the Sahel has contributed to improve farmers' production techniques resulting in an increase of millet yield from $0.42 \mathrm{tha}^{-1}$ to $1.09 \mathrm{tha}^{-1}$ (Alaoui, 2014). Additionally, information initiatives like timely alerts from the community early flood warning system of impending floods to communities living in flood prone areas saved lives and properties as the communities could evacuate to safe grounds before the floods (GoM, 2012c). On the other hand, improved water management through enhanced water recharge in the wetlands, better irrigation farming and enhanced utilization of the wetlands has led to increased adaptive capacity and resilience of the smallholder farmers (GoM, 2012c). Notwithstanding, however, the innovations require scaling up for wider impact in the region.

To scale up these innovations and ensure their long-term sustainability, there is a need to establish effective information dissemination, institutional mechanisms and approaches that are case-specific. Improving communication and access to information on research results and appropriate technologies is essential, especially in remote areas in SSA. Capacity building at all levels should be considered, ranging from the involvement of all actors in innovations development and implementation to the dissemination of knowledge. The level of awareness of smallholder African farmers about climate change and innovative adaptation and mitigation technologies should be increased amongst local communities. Technical know-how needed to implement the improved technologies should be further shared and taught. Evidence based adaptation and mitigation options and success stories of local communities should also be disseminated both by national agencies and the communities themselves for larger impact and adoption of winning strategies. There could also be more collaborative researcher-farmer-consumer initiatives aimed at generating appropriate technologies that could build upon and advance current resilient production and adaptation strategies.

Additionally, research aimed at enhancing and diversifying livelihoods, especially adding value to goods and services to improve the adaptive capacity of communities, has to be intensified, within the context of complex agricultural systems and ecosystems. In the process of generating solutions, participatory methods and multidisciplinary teams have to be involved in order to gain deeper insights of the options and promote their adoption by the farmers. Furthermore, to guide the actions, there is a need for agricultural and natural 
resources management policies to be formulated or revised to incorporate elements that support research of this nature, but also be aligned to the international research focus while creating a conducive policy environment at the same time.

\section{Conclusion}

Climate change is impacting negatively on the productivity of farming systems in SSA. In response, farmers and national Governments in the region have developed innovations and policies to manage the impacts of climate change. Cases are available of innovative adaptive farming systems and technologies that have been developed and implemented with the resultant overall productivity improvement in farming systems. Such innovations, if harnessed and scaled up, could strengthen the resilience and adaptive capacity of vulnerable communities. Commendably, climate governance instruments that are aligned to the ratified international treaties have been developed and related programs have been rolled out in different countries. This offers hope for well-coordinated efforts in the fight against the effects of climate change. There is need however to sustainably scale up climate smart innovations through creation of an enabling policy environment, capacity building, conducting climate change related research and outreach, and effective dissemination of technologies and information, especially in remote areas on the African continent. Since climate change is a global issue, local initiatives and actions for mitigating and adapting to the impacts of climate change ought to be well integrated into the broader international context. Further technological consideration could be the introduction of innovations and technologies capable of increasing productivity with minimal emissions of GHGs. Beyond the rigorous actions aiming at curbing GHGs emissions in SSA and the climate management policies, governments could consider the introduction of carbon tax and crop insurance policies. Observably, climate governance and action are using a top down approach, evidenced by the formulation of plans at global, regional and national level. There is potential however to accelerate climate action through inclusive participatory engagement of stakeholders at all levels of climate action.

Acknowledgment. The authors hereby acknowledge the One Planet Fellowship (OPF) under the African Women in Agricultural Research and Development (AWARD) for constituting the workgroup, the members being among the 2019 cohort of Laureate Candidates-Climate Change. The paper is the output of the Science Week organized by the One Planet Fellowship and held in Casablanca, Morocco from November 25 to December 1, 2019. The authors acknowledge the valuable comments and direction provided by Prof. Sheila Okoth of AWARD.

\section{References}

Akinnagbe OM, Irohibe IJ. 2014. Agricultural adaptation strategies to climate change impacts in Africa: A review. Bangladesh Journal of Agricultural Research 39(3): 407-418. https://doi.org/10.3329/ bjar.v39i3.21984.

Alaoui B. 2014. Innovation Transfer into Agriculture Adaptation to Climate Change (ITAACC). https://www.researchgate.net/publica tion/281319259.
Amsalu A, Gebremichael D. 2010. An overview of climate change impacts and responses in Ethiopia. Ethiopian Environment Review 1: $215-232$.

Crane TA, Roncol C, Hoogenboom G. 2011. Adaptation to climate change and climate variability: The importance of understanding agriculture as performance. NJAS: Wageningen Journal of Life Science 57(3-4): 179-185. https://doi.org/10.1016/j.njas.2010.11.002.

DGEC. n.d. 2020 Benin's First Nationally Determined Contribution under the Paris Agreement. Final report. https://www4.unfccc.int/ sites/ndcstaging/PublishedDocuments/Benin\%20First/CDN_BE NIN_VERSION_ANGLAISE.pdf.

Dje KB. 2014. Document de stratégie du programme national de changement climatique 2015-2020. Programme National Changement Climatique (PNCC). Ministère de l'environnement, de la salubrité urbaine et du développement durable. Direction Générale de l'Environnement, République de Côte d'Ivoire, pp. 1-84.

Fan Y, Park S, Nan Z. 2018. Participatory water management and adoption of micro-irrigation systems: Smallholder farmers in arid north-western China. International Journal of Water Resources Development 34(3): 434-452. https://doi.org/10.1080/ 07900627.2017 .1400424$.

FAO (Food and Agriculture Organization of the United Nations). 2016. AQUASTAT. http://www.fao.org/nr/water/aquastat/data/ glossary/search.html.

FAO. 2018. "FAO'S WORK ON CLIMATE CHANGE United Nations Climate Change Conference 2018", p. 40.

FAO, ICRISAT, CIAT. 2018. Climate-Smart Agriculture in Côte d'Ivoire. CSA Country Profiles for Africa Series. International Center for Tropical Agriculture (CIAT); International Crops Research Institute for the Semi-Arid Tropics (ICRISAT); Food and Agriculture Organization of the United Nations (FAO). Rome, Italy, $23 \mathrm{p}$.

Goula Bi Tié A, Issiaka S, Brou K, Vamoryba F, Gnamien B. 2006. Impact de la variabilité climatique sur les ressources hydriques des bassins de N'Zo et N'Zi en Côte d'Ivoire (Afrique tropicale humide). Vertigo 7(1): 12. https://doi.org/10.4000/vertigo.2038.

Gouvernement de Côte d'Ivoire PNIA. 2017. Program National d'Investissement Agricole de Deuxième Génération. Final Report, 157 p. http://extwprlegs1.fao.org/docs/pdf/IVC176030.pdf.

Government of Kenya. 2018. National Climate Change Action Plan (Kenya): 2018-2022. Nairobi: Ministry of Environment and Forestry, $36 \mathrm{p}$. http://www.environment.go.ke/wp-content/uploads/ 2020/03/NCCAP_2018-2022_ExecutiveSummary-Compressed-1. pdf.

Government of Malawi. 2012a. National Climate Change Response. Draft White Paper. Lilongwe: Ministry of Environment and Climate Change Management, Environmental Affairs Department.

Government of Malawi. 2012b. National Climate Change Policy. Lilongwe: Ministry of Environment and Climate Change Management, Environmental Affairs Department. http://www. cepa.org.mw/index.php/en/2015-02-13-13-10-21/legislation/poli cy-documents? task=download\&id=93.

Government of Malawi. 2012c. Climate Change Adaptation and Mitigation Best Practices in Malawi. https://ees.kuleuven.be/ klimos/toolkit/documents/354_Malawi_CCAM.pdf.

Government of Malawi. 2013. National $\bar{C}$ limate Change Investment Plan. http://10.150.35.18:6510/www.1se.ac.uk/GranthamInstitute/ wp-content/uploads/laws/8198.pdf.

Government of Malawi. 2016. National Climate Change Management Policy. https://reliefweb.int/sites/reliefweb.int/files/resources/ NCCM-Policy-Final-06-11-2016.pdf.

Government of Malawi. 2021. Malawi's Strategy on Climate Change Learning. https://www.uncclearn.org/wp-content/uploads/2021/ 02/Updated-Malawis-Strategy-on-Climate-Change-Learning2021.pdf. 
Hesse C, Pattison J. 2013. Ensuring devolution supports adaptation and climate resilient growth in Kenya. IIED Briefing PaperInternational Institute for Environment and Development, 17161, 4 p. https://pubs.iied.org/17161iied.

IIED. 2004. Adverse impacts of climate change and development challenges: Integrating adaptation in policy and development in Malawi. Capacity strengthening in the least developed countries (LDCs) for adaptation to climate change (CLACC). http://pubs. iied.org/pdfs/10013IIED.pdf.

IFAD. 2015. Programme for Rural Irrigation Development Detailed design report. Main report and appendices. East and Southern Africa Division Programme Management Department. https:// www.ifad.org/fr/web/operations/-/project/1100001670.

Irish Aid. 2018. Ethiopia Country Climate Risk Assessment Report. Irish Aid, Resilience and Economic Inclusion Team, Policy Unit February, 2018. https://www.climatelearningplatform.org/sites/de fault/files/resources/ethiopia_country_climate_risk_assessment_re port_final.pdf.

International Institute for Sustainable Development. 2018. Benin's National Assembly Passes Climate Change Legislation. Accessed: 05/01/2021. [Online]. http://sdg.iisd.org/news/benins-national-as sembly-passes-climate-change-legislation/\#: :text=National $\%$ 20 climate $\% 20$ change $\% 20$ legislation $\% 20$ adopted, and $\% 20$ pro grammes $\% 20$ incorporate $\% 20$ climate $\% 20$ change.\&text $=$ The $\%$ 20law $\% 20$ requires $\% 20$ that $\% 2 \mathrm{C} \% 20$ going,and $\% 20$ programmes $\%$ 20 incorporate $\% 20$ climate $\% 20$ change.

Jansen K, Vellema S. 2011. What is technography? NJAS: Wageningen Journal of Life Sciences 57: 169-177. https://doi. org/10.1016/j.njas.2010.11.003.

Kamdonyo DR. 2019. Malawi gears up to adapt to climate change. http://napglobalnetwork.org/2019/09/malawi-gears-up-for-its-cli mate-change-adaptation/.

Krell NT, Giroux SA, Guido Z, Hannah C, Lopus SE, Caylor KK, et al. 2020. Smallholder farmers' use of mobile phone services in central Kenya. Climate and Development 13(3): 215-227. https:// doi.org/10.1080/17565529.2020.1748847.

Magoum I. 2020. Côte d'Ivoire: Country progresses in climate change control. https://www.afrik21.africa/en/cote-divoire-country-pro gresses-in-climate-change-control/.

Nath AJ, Sileshi GW, Laskar SY, Pathak K, Reang D, Nath A, et al. 2021. Quantifying carbon stocks and sequestration potential in agroforestry systems under divergent management scenarios relevant to India's Nationally Determined Contribution. Journal of Cleaner Production 281: 124831. https://doi.org/10.1016/j.jclepro.2020.124831.

Nyasimi M, Radeny M, Kinyangi J. 2013. Climate change adaptation and mitigation initiatives for agriculture in East Africa. CCAFS Working Paper no. 60. Copenhagen, Denmark: CGIAR Research Program on Climate Change, Agriculture and Food Security (CCAFS). https://ccafs.cgiar.org/resources/publications/climatechange-adaptation-and-mitigation-initiatives-agriculture-east.
Nzau VM. 2014. Climate change financing in Kenya. International Institute for Environment and Development (2014) Stable URL: http://www.jstor.com/stable/resrep01573.

Rajendran S, Afari-Sefa V, Shee A, Bocher T, Bekunda M, Dominick I, et al. 2017. Does crop diversity contribute to dietary diversity? Evidence from integration of vegetables into maize-based farming systems. Agriculture \& Food Security 6: 50. https:// doi.org/10.1186/s40066-017-0127-3.

Republic of Benin. 2011. Deuxième communication nationale de la république du Benin sur les changements climatiques. https:// unfccc.int/resource/docs/natc/bennc2f.pdf.

Shimeles A, Verdier-Chouchane A, Boly A. 2018. Building a resilient and sustainable agriculture in Sub-Saharan Africa. Cham (Switzerland): Palgrave Macmillan, 315 p. https://doi.org/ 10.1007/978-3-319-76222-7.

Simane B, Beyene H, Deressa W, Kumie A, Berhane K, Samet J. 2016. Review of climate change and health in Ethiopia: status and gap analysis. The Ethiopian Journal Health Development 30(1): 28-41.

Soglo YY, Nonvide GMA. 2019. Climate change perceptions and responsive strategies in Benin: the case of maize farmers. Climate Change 155: 245-256. https://doi.org/10.1007/s10584-019-02452-3.

Tye S, Waslander J. 2021. Mainstreaming climate adaptation planning and action into health systems in Fiji, Ghana, and Benin. Working Paper. Washington DC (USA): World Resources Institute, 28 p. https://doi.org/10.46830/wriwp.19.00119.

UNFCCC. 2015. The Paris Agreement. https:/unfecc.int/processand-meetings/the-paris-agreement/the-paris-agreement.

USDA. 2021. Mali Overview on Climate Change Policy. Voluntary Report-Voluntary-Public Distribution. Report Number: SG2021-0010.

Yapi LL. 2019. Comprendre et promouvoir les CDN pour mieux sensibiliser sur les défis climatiques. Programme National Changement Climatique (PNCC). CERAO, pp. 1-20.

Yegbemey RN, Yegbemey EO, Yabi JA, 2017. Sustainability analysis of observed climate change adaptation strategies in maize farming in Benin, West Africa. Outlook on Agriculture 46(1): 20-27. https://doi.org/10.1177\%2F0030727016689638.

Zamudio AN. 2016. Review of current and planned adaptation action in Mali. CARIAA Working Paper no. 11. International Development Research Centre, Ottawa, Canada and UK Aid, London, United Kingdom. www.idrc.ca/cariaa.

ZEF, FARA, IEA. 2017. Country Dossier. "Innovation for Sustainable Agricultural Growth in Mali”. [2020/06/23]. https://research4a grinnovation.org/wp-content/uploads/2017/10/MaliDossier2017. pdf.

Zougmoré R, Partey S, Ouédraogo M, Omitoyin B, Thomas T, Ayantunde A, et al. 2016. Toward climate-smart agriculture in West Africa: A review of climate change impacts, adaptation strategies and policy developments for the livestock, fishery and crop production sectors. Agriculture \& Food Security 5: 26. https://doi. org/10.1186/s40066-016-0075-3.

Cite this article as: Afokpe PMK, Phiri AT, Lamore AA, Toure HMAC, Traore R, Kipkogei O. 2022. Progress in climate change adaptation and mitigation actions in sub-Saharan Africa farming systems. Cah. Agric. 31: 4. 